\title{
Strategic Services Policies and International Trade Integration in Vietnam
}

\author{
Alberto Gabriele \\ World Food Programme
}

\begin{abstract}
The aim of this paper is to analyze Vietnam's services policies and to evaluate their effectiveness and consistency, in the framework of the country's increasing international economic integration. Among the various services sectors, the paper focuses specifically on a sub-group, namely strategic services, (and on energy and telecommunications in particular. The paper is organized as follows. The introduction sketches a few basic facts about the Vietnamese economy. Section 1 underlines the key role of strategic services, and describes the main tenets of economic reforms in the domain of services. Section 2 analyzes the international trade dimension of services policies in Vietnam, presently characterized by the recent signing of the Bilateral Trade Agreement (BTA) with the US and by the ongoing multilateral negotiations aimed at accessing the WTO. Section 3 focuses on Vietnam's policies in the area of strategic services, with particular attention for energy and telecommunications. Section 5 proposes a few conclusive remarks. The Annex reports a few basic facts and figures on Vietnam's services sector.
\end{abstract}

- JEL Classifications: D4, H4, L3, L8, L9, O3, O4, P2, P4

- Key words: Services, Vietnam, Trade, Integration, SOEs, Monopoly, Privatization, Public enterprises

\footnotetext{
*Corresponding address: Alberto Gabriele, World Food Programme, Via Cesare Giulio Viola 68/70, Parco de Medici, 00148 Rome, Italy, Tel: +39-06-8072716, E-mail: alberto.gabriele@wfp.org C2005-Center for International Economics, Sejong Institution, All Rights Reserved.
} 


\section{Introduction}

Vietnam is a large, ${ }^{1}$ low-income, East Asian country, whose present, modest level of economic development is historically attributable mainly to the successive wars which have plagued it during most ${ }^{2}$ of the past century. After reunification, Vietnamese economic policies initially followed a traditional, socialist development strategy. However, after a rather short period of time ${ }^{3}$ that strategy was perceived by policy makers to be unsustainable, due both to its intrinsic weaknesses and to profound changes in the international political and economic scenario. After over two decades of sustained restructuring efforts, a relatively consistent, albeit fastevolving model has emerged under the "doi moi" (renewal) strategy ${ }^{4}$, and the Vietnamese government is presently committed to a long-term strategy based on developing a market economy with a socialist orientation.

The reforms allowed Vietnam to overcome the late-1970s crisis and to achieve respectable growth over the $1980 \mathrm{~s}^{5}$, although high inflation and large macroeconomic imbalances persisted.

Thanks to factors as the egalitarian distribution of productive assets at the inception of doi moi, the moderate pace of market-driven concentration of such assets so far, and the full participation of agriculture to the process of economic development, "the growth path experienced by Vietnam in the 1990s was remarkably pro-poor” (World Bank 2003, p. vi. See also IMF-IDA 2002, GOV 2000b, Xuan Gia

\footnotetext{
${ }^{1}$ Vietnam's population was over 80 million in 2002, ranking 13th among all countries in the world.

${ }^{2}$ The anti-colonialist movement started long before the August 1945 revolution, and Vietnam's heavy military engagement in Cambodia ended only in 1989.

${ }^{3}$ The economic policies of the Democratic Republic of Vietnam between 1945 and 1975 are to be seen as war economy policies, rather than socialist development policies (and, as such, were effective and largely inevitable in their own way, and not very different from those pursued even by many capitalist countries under comparable dramatic circumstances). Unified Vietnam's "Soviet-style" period lasted for barely a decade, the shortest record among all presently-existing Communist-led developing countries.

${ }^{4}$ To face the systemic crisis conditions which prevailed in the late 1970s, in the autumn of 1979 the $6^{\text {th }}$ Plenum of the Central Committee sanctioned already going-on reforms from below, mainly in the agricultural sector. Stop-and-go reforms continued to be implemented in the early 1980s, and the "doi moi" policy was officially lunched in the $6^{\text {th }}$ Party Congress in December 1986.
}

\footnotetext{
${ }^{5}$ National income growth rates per year averaged $6.4 \%$ in $1981-1985$ and $4.4 \%$ in $1986-1990$. Agricultural production outpaced population growth, and industrial production expanded at over $9 \%$ per year in the first half of the decade, although it slowed at a little more than 4\% rate in 1986-1990 (Source: Fforde and de Vylder 1996, quoted in Masina 2003, table 2.1., p.57).
} 
2003). The virtuous combination of very fast growth and absence of a strong anti-poor bias led Vietnam to achieve extraordinary good results in the domain of poverty reduction, and quite good results in improving social indicators. In fact, Vietnam has achieved one of the sharpest declines in poverty of any developing country on record, as its (absolute) poverty rate fell from about $70 \%$ in the 1980 s to $29 \%$ in $2002^{6}$ (World Bank 2003, Larsen et al. 2003).

Since the success of the 1989-1990 stabilization plan, inflation subdued, basic macroeconomic and systemic stability was achieved, and Vietnam became one of the fastest-growing countries in the world (See Table A1). ${ }^{7}$ Most Vietnamese still leave in rural areas, but industry is now the leading economic sector. Yet, services have also been expanding at a rapid pace, and by the early 2000s they accounted for almost one half of GDP and for the bulk of non-agricultural employment (see Annex, Tables A1. and A2).

\section{Strategic Service Policies in the Framework of the Doi Moi Reform Process}

\section{A. The key role of strategic services}

Among the various services activities, this paper focuses mainly on Vietnam's strategic services sectors. For their direct and indirect supporting and enabling functions and their crucial role in providing physical and human capital, strategic services are instrumental and in fact indispensable both for the everyday functioning and for the long-run development of the economy as a whole. By definition, strategic services have a strong and recognizable impact on each country's development perspectives, and therefore no government can just leave them to the vagaries of the market. Accordingly, strategic services are very different from commercial services, consisting in those ordinary service activities, which by and large can, and in fact should be left to the spontaneous regulation of market forces. $^{8}$

\footnotetext{
${ }^{6}$ According to an alternative methodology, which sets the absolute poverty line slightly lower, Vietnam's poverty rate is below $20 \%$. In terms of the Human Poverty Index Vietnam ranks 39th out of 94 countries (UNDP 2003).

${ }^{7}$ According to UNDP 2003 (Table 12) the highest GDP per capita annual growth rate in 1990-2001 was recorded by Equatorial Guinea with an astonishing 18.8\%. Apart from this statistical curiosum, the highest rate was that of China (8.8\%), followed by Vietnam $(6 \%)$.
} 
State intervention in strategic services can take various forms, be compatible with diverse forms of market structure and regulation, and involve or not their direct provision through SOEs. The core of strategic services is constituted by mature and advanced capital- and skill-intensive infrastructural services industries, such as energy industries, transportation, and telecommunications, besides a number of other infrastructural services characterized by a wide range of technologies, among which the network of large- and small-scale irrigation facilities is particularly important in a largely rural developing country like Vietnam. Yet, in a slightly more indirect sense, the financial sector is also a strategic one, taking into account its crucial role in enabling investment activities, reducing transaction costs, and fostering macroeconomic stability. ${ }^{9}$ Other strategic services, aimed at fostering the accumulation of highly-skilled human capita and the absorption and development of new ${ }^{10}$ technologies, are "lighter" in nature: this is the case of R\&D and higher education activities (in the GSO classification, they would broadly correspond respectively to the Science and Technology sector and to the higher echelons of Education and Training sector). While the strategic importance of R\&D is selfevident, the policy approach to higher education activities faces particularly complex challenges, as the strategic nature of this service overlaps with its social dimension, and the very boundary between basic and higher education is a matter of policy choice.

\section{B. Main reform initiatives affecting services in the doi moi period}

The doi moi reform strategy was officially launched in the important $6^{\text {th }}$ VCP Congress in December 1986. Besides increasing SOEs' managerial and operational autonomy, the Congress unleashed a major liberalization drive in two crucial

\footnotetext{
${ }^{8}$ To my view, social services - such as health and education - can also entail a strategic dimension, but they require a totally different policy approach from those suitable to non-social (both strategic and commercial) service activities. However, the issue of the relationship between social and non-social services policies lies beyond the scope of the present paper.

${ }^{9}$ By the same token, also public administration services, and more broadly all the services supplied by the whole set of non (directly) productive public and private institutions are strategic. In fact, and taking into account the central role presently attributed to the issue of "governance", they are in fact "the" most strategic of all services,. especially in the context of an institutionalist approach to development problems. However, administrative and institutional reforms constitute an area of government policies which, due to its very specificity and complexity, is quite distinct to that of economic policies in the other services sectors.

${ }^{10}$ In the context of developing countries, "new" technologies are those new to the country, even if they might not be so in more advanced countries. In the early stages of development, the ability to absorb and adapt already existing technologies from abroad is more important than the ability to innovate in the proper sense.
} 
services areas: private (mainly small scale) commercial activities were allowed, along with productive activities, and the official state monopoly on foreign trade was formally abolished. Thus, commercial services in Vietnam (which, as a legacy from the American War period, were more developed in the Southern part of the country) came to be increasingly, and in fact almost exclusively, regulated by market forces. Commercial service enterprises are mostly individual or family businesses and SMEs, although some larger private services enterprises are also emerging. Yet, SOEs continued to be active, and some of them are still in a relevant, although relatively declining position, in several commercial sub-sectors (among them international trade and tourism), while cooperatives play a complementary role. Social sectors, severely weakened by the reforms especially in rural areas, were also opened to market forces and private participation, but the role of public education and health systems remained central.

Since the 6th Party Congress, a number of major market-oriented and liberalizing reforms have been launched during the doi moi period, many of them affecting directly or indirectly service activities. However, the policy approach to strategic sectors was very cautious, and a significant, yet gradual and partial, degree of market liberalization in core infrastructural areas such as energy or telecommunications dates only since the late 1990s. In the domain of financial services, affected by the burden of numerous non-performing loans (NPLs), reforms initiated in the late 1980s, with a shift from a mono-bank system to a two-tier system, as the function of the Central bank was separated from those of 4 State-owned commercial banks (SOCBs). Thereafter, other types of private actors, such as joint stock banks (JSBs), joint venture banks and representative offices, and branches of foreign banks were gradually allowed to enter the Vietnamese financial market. Further reforms of the financial sector figure high in the governments' agenda. A clear option in favor of the Asian model, in which the state retains its ability to channel resources towards strategic sectors through the control of the financial system, or towards a neutral, laissez faire alternative, has not been made explicit yet. However, the government is careful to avoid the risks of hasty financial liberalization, a fortiori especially after learning the sobering lesson from the Asian crisis, from which Vietnam substantially escaped thanks to its relative insulation from unregulated international financial flows.

\section{The role of FDI and the "healthy" impact of the Asian financial crisis}

In the 1990s, Vietnam began attracting an increasing flow of foreign direct 
investment, a large part of which went to services and service-related activities. The investment flow was modest in absolute size, but large with respect to the limited level of development and sheer dimension of the Vietnamese economy. Actually, following at a smaller scale a pattern common to other Asian countries, an excessive amount of foreign financing went to scarcely productive service activities, such real estate, urban construction, hotels, and tourism. When the regional crisis erupted, FDI inflows experienced an abrupt decline, causing Vietnam's overall investment rate to fall from $29 \%$ to $19 \%$ between 1997 and 1999. However, Vietnam did not suffer a GDP drop in 1998, resumed rather easily a fast development path, and indirectly benefited to some extent from the FDI realignment caused by the crisis. ${ }^{11}$ Actually, most of the overall FDI decline in Vietnam was caused more by the dramatic cash needs on the part of East Asian investors, hit by the regional crisis in their home countries, than by domestic factors. The result was a halt of what was becoming a classical real estate bubble, mainly concentrated in office property and apartments: such foreign investments were already almost US\$1.9 billion in 1995, ballooned at US\$3.4 billion in 1996 and fell to only US $\$ 0.2$ billion in 1997. As a percentage of total FDI, real estate dropped from over 40\% in 1995 and 1996 to less than 8\% in 1997 (Masina 2003, pp. 76 - 77). Yet, commitments to other services sectors, including telecommunications, increased. These figures show that commercial services were already becoming an important recipient of FDI. They also suggest that if external factors (such as the regional crisis) or decided policy interventions had not put a halt to such an unhealthy trend of speculative financial inflows, the risk of a sudden financial crisis of the kind of those which hit Thailand and Indonesia could have become a real possibility. Another paradoxically positive effect of the regional crisis on Vietnam's services sector was that it helped to re-balance the sectoral composition of FDI, contributing to avoid a disproportionate expansion of scarcely productive and speculation-prone services sub-sector such as real estate.

In the aftermath of the crisis, Vietnam's economic policy stance did not experience major shifts. Policy makers were actively promoting Vietnam's regional and international economic integration, leading to the signing of the major AFTA and BTA trade agreements and continuing WTO accession negotiations. The most

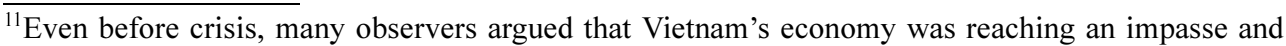
without further dramatic liberal reforms growth would falter, blaming as usual inefficient SOEs and banks, insufficient export-orientation, and a persisting protectionist bias in trade policies in favour of import substitution. These views were proved wrong by Vietnam's resilience to the crisis and the swift recovery in GDP and export growth ( see Masina 2003, Kokko 1998).
} 
important policy measure was the approval of the new enterprise law, operational since January 2000. The law made it much easier to launch new individual and private enterprises, and to legalize existing informal ones. In just 2 years, the law led to the licensing of 36000 new private SMEs, six times more than in 19981999. Most of these new firms were small and active in commercial services, although an increasing minority was constituted by private industrial firms, some of them relatively large.

The 9th Party Congress, held in April 2000, confirmed the established tenets of Vietnam's development strategy. After a long preparatory debate and consultancies process, carried out both with internal constituencies and international organizations, the congress approved two important long-tern strategic documents, the Strategy for Socioeconomic Development 2001/2010(GOV 2000a) and the 5-year plan for Socioeconomic Development 2000/2005 (GOV 2001a). ${ }^{12}$ The two documents are short in indicating precise ways to achieve the approved goals and targets, and the contain few clear-cut strategic formulations. Yet, taking into account that they reflect a sort of compromise, or mutual understanding with international financial institutions, both documents are significant, as they mark a shift away from structural adjustment jargon, towards a broad poverty reduction strategy. Therefore, they signal some distancing from previous Washington Consensus formulae and the emergence of a new emphasis on poverty reduction as the true goal of economic development.

\section{Services Policies: The International Trade Dimension}

\section{A. The defensive stance of Vietnam's international trade policies on services}

As late as 2001, Yusuf and Stiglitz wrote: “...the WTO...allows nations to lock in unilateral trade liberalization - a vital action for development. Of equal importance will be institutional steps to stimulate trade in services, which is likely to be the fastest-growing component in the future" (Yusuf and Stiglitz 2001). There is surely no dispute on the central role of international trade in services in

\footnotetext{
${ }^{12}$ The Congress also prepared the ground for the preparation and approval of other important policy documents, among them the Hunger Eradication and Poverty Reduction Strategy (GOV 2001b), the Comprehensive Poverty Reduction and Growth Strategy (CPRGS)( GOV 2002), and two important directives in the domain of social services: the Vietnamese Education and Training Development Strategy to the Year 2010 for the Cause of the Industrialization and Modernization of Vietnam (GOV 2001c) and the Prime Minister's Decision on Approval of Strategy for People's Health Care and Protection 2001-2010 (GOV 2001d).
} 
shaping contemporary development prospects. However, the failure of the WTO meeting in Cancun in September 2003 invites to more prudence, both in taking for granted the sustainability of a smooth path of further multilateral liberalization of trade in services, and in considering such an eventuality an unambiguous blessing. Actually, besides developed countries' lack of flexibility on moderating agricultural protectionism, the breakdown of the Cancun negotiations was due to developing countries' progressive realization of the risks and imbalances implied by the socalled Singapore issues ${ }^{13}$ and by the increasing pressure towards a full liberalization of international trade in services.

In sum, the future of the overall process of multilateral trade liberalization, which until the late 1990s could be seen as unstoppable and universally benign force, is now mired in deep uncertainty. Recent developments in the multilateral arena appear to vindicate the wisdom of Vietnam's cautiousness and defensiveness ${ }^{14}$ in approaching negotiations on international trade in services. ${ }^{15}$

In fact, the "external dimension" of Vietnam's services policies so far has focused mainly on managing successfully the transition from closed and often monopolistically regimes to fully or partially competitive market structures, involving the participation of foreign enterprises. In other words, the emphasis has been a defensive one, centered on domestic markets, rather than an offensive one aimed at conquering foreign markets. This bias is correct, given the present and even perspective level of international competitiveness of Vietnamese strategic services sectors. Actually, in the case of BTA as well as in that of the on-going WTO accession negotiations, it is a well-known fact that the crucial bargaining game has been one in which Vietnam offers concessions on services in order to obtain concessions on goods.

Consistently with this policy focus, in the domain of goods, Vietnam has enacted

\footnotetext{
${ }^{13}$ The Singapore issues refer to investment, government procurement, trade facilitation and competition.

${ }^{14}$ Such prudent attitudes have not held back Vietnam from making a bold, possibly hazardous, but probably inevitable step in signing the BTA, which is analyzed in the following sub-section.

${ }^{15}$ The Vietnamese government carefully avoids confronting on ideological grounds the mainstream view on globalization and the magic of markets heralded by donors and international financial institutions (see Masina 2003). Yet, such pragmatism is not grounded in a naïve perception of the reality of international economic relations. The Strategy for Socio-Economic Development 2001-2010, for instance, recognizes that "Economic globalization and international economic integration constitute a process of cooperation for development on the one hand, and complicated struggle on the other, especially the struggle of developing countries in defense of their interests, for an equitable international economic order, against unreasonable impositions by economic powers and transnational corporations" (Government of Vietnam (GOV), 2000a, Section I).
} 
a number of direct and indirect measures aimed at promoting the exportation of light manufactures ${ }^{16}$, where the country does have comparative advantage. Conversely, there is little in Vietnam's economic policy resembling specific measures aimed at fostering the exportation of services. ${ }^{17}$ However, on balance, Vietnam's policies in the domain of trade in services can essentially be understood analyzing its trade diplomacy activities.

Although Vietnam has been involved in an increasing number of trade negotiations tables, leading to the signing of many bilateral and multilateral agreements, the most important one so far has been the Bilateral Trade Agreement (BTA) with the United States. ${ }^{18}$ This is particularly true with respect to services, as the regional AFTA agreement says little on services liberalization. With respect to WTO negotiations, they are still in a fluid state, but a brief analysis of Vietnam's offer on services can shed some light on negotiators' stance and priorities at the multilateral level. Therefore, the remaining of this section focuses on the most important provisions of the BTA on bilateral trade in services and on Vietnam's negotiating offer on services, with particular attention for the pivotal telecommunications sector.

\section{B. The BTA: a gradual but very deep process of liberalization of trade in services}

The BTA is the most comprehensive and extensive trade agreement ever signed not only by Vietnam but also by the US (STAR-CIEM 2003, p.111). Some commitments on the part of the Vietnamese side were due immediately at the entry into force of the agreement (December 10 2001), but most were phased in over $3-4$ years periods, and one over a ten year period. The US, on its part, gave Vietnam a Normal Trade Relations and Most Favored Nation (NTR/MFN) trade status effective immediately, thereby reducing average US tariff rates for Vietnamese exports to the US from $40 \%$ to around $3-4 \%$. Notwithstanding this relatively favorable temporary asymmetry in the implementation schedule, the fact remains

\footnotetext{
${ }^{16}$ Taking into account the constraints constituted by Vietnam's limited capabilities as a developmental state, and by the low degree of flexibility in policy interventions allowed by the present international economic and trade context, many of such interventions can be interpreted as consistent with the classical Asian outward-oriented industrial policies paradigm.

${ }^{17}$ During future trade negotiations, the government should accord some additional attention to enhancing Vietnamese operators' access to foreign services markets, especially with respect to tourism and to other potentially foreign-exchange earning commercial services sectors.
}

\footnotetext{
${ }^{18}$ See Government of Vietnam (GOV) and Government of the U.S. of America, 2001.
} 
that Vietnam's BTA commitments go far beyond what the reform process had accomplished at the time of signing of the agreement, thus placing "significant demands on Vietnam's legal system" (STAR-CIEM 2003, pp.112-115). Besides according MFN and National Treatment to US companies and nationals, in fact, Vietnam is expected to implement a number of liberalizing reforms, such as increasing transparency, cutting red tape, and enhancing intellectual property rights (IPR) protection. ${ }^{19}$

Vietnam's commitments provide several forms of guarantees to US investors. ${ }^{20}$ Yet, horizontal liberalization is not fully unconstrained, as some limitations remain, the most significant being relative to market access ${ }^{21}$, as US service providers are subject to licensing. ${ }^{22}$ Along with such extensive "horizontal" commitments, the core of Vietnam's BTA concessions is constituted by the undertaking to carry out a

\footnotetext{
${ }^{19}$ IPR protection provisions in BTA are wide and deep. All conventions on IPR, starting with the Geneva one, are to be "given effect as a minimum" and the national treatment principle is strongly affirmed (Chapter II, Art.3). Copyright protection, extending inter alia to audiovisual works, is quite extensive and detailed (Art 4). Patent protection is also strong: as a general rule, patents are protected for a period of no less than 20 years- much longer than the period established in Vietnam's ordinary IPR legislation (7 years), although the government has expressed the intention to revise it upwards (see VBF 2003). Yet, potentially relevant limitations on patentability of medical and biological technologies are stated in comma 2, Art 7: it says "Parties may exclude from patentability..."diagnostic, therapeutic and surgical methods...essentially biological processes for the production of plants or animals other than nonbiological and microbiological processes; animal varieties; plant varieties...” (see BTA 2001).
}

${ }^{20}$ To ensure these commitments are effective, BTA calls for transparent and objective domestic regulation for services, limiting abusive behavior of monopoly suppliers and buyers, and includes many obligations mutuated from GATS, incorporating in full the GATS Annex on Telecommunications, the WTO telecommunications Reference Paper, the GATS Annex on Financial Services, and the GATS Annex on the Movement of Natural Persons.

${ }^{21}$ Article 6 of Chapter III regulates market access in trade in services. It establishes that parties shall not maintain or adopt measures to restrict market access, in sectors where market-access commitments are undertaken. A potentially delicate principle is established in a note to paragraph 1 (Note 4) of article 6, which establishes that, if a party undertakes market-access commitments in relation to the supply of a services, it must allow cross-border capital movements if they are "essential" parts of the service itself. Although sensible and advisable per se, an unwise and unwarrantedly automatic application of this principle might conflict with the basic prudential and sovereignty-related objective of preserving a basic control on the capital account of the balance of payments, the crucial importance of which has been emphasized by the Asian crisis.

${ }^{22}$ Vietnam's BTA commitments on services can also be compared to the corresponding WTO commitments of China and several other countries which acceded in recent years (Taiwan, Jordan, Oman, Armenia, Macedonia, Moldova, Lithuania, Croatia, Albania). Broadly speaking, Vietnam's commitments appear to be relatively cautious and quite similar to those of China and, to a lesser extent, to those of Taiwan. In the case of telecommunications, in particular, Both Vietnam's and China's commitments are particularly complex, articulated, and gradual (See US Vietnam Trade Council 2003). 
sweeping and profound liberalization of trade in services. Over 20 services sectors are specifically targeted for liberalization, including): business services; communication services such as telecommunications (value-added and internet, basic, and voice) and audiovisual services-; construction and related engineering services; distribution services; education services; financial services; health services; tourism and travelrelated services. ${ }^{23}$

Among these services sectors, telecommunications services are the most delicate and strategically important. ${ }^{24}$ The most substantial liberalization will take place in the domain of commercial presence of foreign enterprises in the Vietnamese telecommunications market, although a few residual but crucial limitations are maintained. Commercial presence of US corporations is initially allowed only in the form of a business cooperation contract (BCC) with an authorized Vietnamese partner. Joint ventures cannot construct their own long distance and international circuit but have to lease from Vietnamese operators.

In sum, the BTA, like the WTO agreements, is "modern", as it includes extensive obligations referring not only to tariffs and quotas, but also to issues such as transparency, dispute settlement, investment, IPR protection, business facilitation and, of course, market access for services. In fact, BTA obligations go far beyond ordinary WTO standards, as the agreement contains specific and detailed chapters on a number of issues which are still only partially covered in the WTO Agreements and/or are presently the object of intense multilateral negotiations, such as intellectual property rights, trade in services, investment relations, business facilitations and transparency. Yet, the BTA is less articulate in disciplining bilateral trade relations with respect to the eventuality of one of the parties recurring to what the other might consider unfair trade practices. For instance, it does not contain specific provisions on anti-dumping measures, and hence it proved ineffective in preventing the ugly dispute on catfish which erupted in 2002-2003. The dispute ended up with the US imposing very high tariffs on Vietnamese catfish exports, on the unlikely ground that Vietnamese producers would have been unfairly subsidized by the government. This protectionist measure caused Vietnamese exporters (most of them rural household-sized businesses or SMEs) a huge loss.

\footnotetext{
${ }^{23}$ Most commitments are phased in over periods varying between year 2 December 2003) and year 7 (Dec 2008), but one (relative to commercial presence in banking) extends to year 10 (Dec 2011).

${ }^{24}$ Telecommunications also rank very high among the priorities of Vietnamese and WTO members' delegations engaged in the country's ongoing WTO accession negotiations.
} 
In spite of the ugly catfish story, there is little doubt that the impact of BTA on the Vietnamese economy has been a success in the short term. Vietnam's total exports to the American market more than doubled between 2001 and 2002, and manufactured exports increased 500\%. Garments exports, in particular reached 0.9 billion dollars in 2002, surging by over $1700 \%{ }^{25}$ (see STAR-CIEM 2003, fig. 14, p.120). However (as the Vietnamese planners know very well) these initial results, while heartening, cannot be considered as fair predictors of the long-run impact of the BTA. The reason, basically, is that because so far, from the Vietnamese vantage point, only the benefits have started to manifest themselves, while the costs have yet to materialize, as most of Vietnam's obligations are due to mature only later, starting from end 2003. The long-run impact of the agreement on the Vietnamese economy, and especially on Vietnam's services sector, is still an open bet.

\section{Vietnam's WTO offer on services}

Vietnam is presently in an advanced stage of its WTO accession negotiations. The determination and clearness of political will on the part of the Vietnamese government to achieve a positive result, which is seen also symbolically as a crowning and final vindications of all the trade policy reforms carried out since the start of doi moi, are increasingly apparent. Yet, negotiations have been dragging on for a while, especially on trade in services, as WTO members (following a pattern which has been repeated once and again in negotiations with new WTO candidates) utilize their bargaining power in order to push the acceding country towards a degree of multilateral trade liberalization which goes far beyond the one to which the founding WTO countries originally committed, or are willing to commit in the foreseeable future. In the case of Vietnam, this means that WTO members, and especially non-US OECD countries, take it for granted that it is not worth talking about anything less than "BTA-plus", e.g. a degree of multilateral commitments which fully matches those already undertaken bilaterally with the US, and possibly going further (see Nhat et al. 2001, Schmidt 2002). Up to mid2003, Vietnam did not appear to have fully accepted the merits of such a realpolitik approach, as its March 2003 Offer on Specific Commitments in Services, while quite generous in general terms, fell short of some WTO members' expectations, especially in the domain of market access in trade in services. ${ }^{26}$ The most controversial sector,

\footnotetext{
${ }^{25}$ Garments are now by far the most important component of Vietnam's merchandise exports to the US, followed by fish and seafood and footwear.
} 
again, was telecommunications, where Vietnam pledged to permit commercial presence only through BCCs (as it is presently the case) in voice telephone and basic telecommunications, while joint ventures with Vietnamese partners would be allowed in the sub-sector of value-added services after the date of accession, with a permanent limitation of $49 \%$ on the foreign side's capital contribution (GOV 2003). WTO member's complaints were obviously framed in an overall context characterized by extremely unequal bargaining strengths, exacerbated by the permanent coordination of negotiating strategies among OECD (and especially Western $^{27}$ ) members. Nevertheless, it is true that, if the march offer had been accepted without changes, it would practically have left even already-established non-US players (such as the Australian telecommunications company TELSTRA) at a competitive disadvantage vis a vis US companies, as presently only the latter are permitted under BTA to form joint ventures with Vietnamese partners.

In October, 2003, Vietnam put forward a revised offer on services, which contained a further degree of specification of the proposed liberalization schedule, its technical modalities, timing, and transparency requirements. The new offer also contained new sector-specific pledges in sectors such as financial services, maritime transport, audiovisual and cultural services, and telecommunications. In the latter sector, in particular, foreign companies were allowed the possibility of forming joint ventures with Vietnamese partners.

In spite of the delays caused by the remaining disagreements on Vietnam's commitments on trade in services, ${ }^{28}$ it is easy to forecast that - barring major disruptions either in the domestic or in the international political and economic

\footnotetext{
${ }^{26}$ According to some observers, Vietnam's negotiating strategy might have been also influenced by two factors, both of which militated against hastening the accession process. One is the desire to wait for China's access, in order to have some time to observe its initial impact and to draw some lessons from the neighbor's experience ( as Vietnam appears to have done in many other domains since the inception of doi moi), and also in the hope that China's presence among WTO members might someway help Vietnam's negotiating position. The other is the eventuality of a failure in the new round of WTO negotiations, which might enhance Vietnam's bargaining strength. As mentioned above in sub-section 3.1., WTO negotiations in Cancun did in fact fail spectacularly: however, the assumption that Vietnam is bound to benefit from this new development in the international world trade scenario is far from obvious.
}

${ }^{27}$ I am not aware of any specific position taken by Japan on this specific negotiating issue. Yet, it is apparent that Japan's attitude towards bilateral trade relations and its intellectual and lobbying influence on the formulation and implementation of Vietnam's national development strategy has been consistently different from that of other major OECD countries, favoring an "Asian developmental state" - style approach rather than the standard Washington Consensus prescriptions.

\footnotetext{
${ }^{28} \mathrm{~A}$ new round of negotiations, initially scheduled to take place in September, 2003, is now expected to
} take place in early 2004 . Vietnamese negotiators are preparing a new offer on services. 
situation - a solution will be found before long, on a compromise ground that will see Vietnam concede still some more ground to present WTO members in terms of trade liberalization, especially in the domain of services. Chances that accession will be completed by the target year 2005 now appear fairly high.

\section{Policies in the Area of Strategic Services}

\section{A. The high user cost of core infrastructural services}

Notwithstanding the market-oriented reforms and the extraordinary rate of development of the Vietnamese economy as a whole, and in particular of prioritized infrastructural sectors, by the early 2000s the costs and efficiency of key service industries such as energy, telecommunications and (to a lesser extent) transportation still relatively penalized enterprises operating in the Vietnamese market vis a vis those active in many other Asian countries. Such a disadvantage stems in part by the relative underdevelopment of these service industries, and in part from a deliberate tariff policy (now being gradually revised) which aimed to strengthen financially large, strategic SOEs, especially in the energy and telecommunications subsectors.

Comparatively high telecommunications tariffs are constantly mentioned by Vietnamese and foreign businesspeople alike as a major constraint to their ability to compete successfully both in domestic and international markets. One recent occasion when these grievances have been aired with particular emphasis was the mid-year Consultative Group Meeting of the Vietnam Business Forum, held in Hanoi on June 6, 2003. During that meeting, a series of data were presented to substantiate the claim that the relative underdevelopment and high costs of telecommunications and a few other key services were pushing up the "cost of doing business", thereby undermining the competitiveness of Vietnamese industry.

It is worth to have a closer look at these figures, which are also helpful to visualize Vietnam's business climate conditions in comparison to those of other Asian countries. Table 1 shows that telephone and electricity costs are much higher in Vietnam than in other countries. Yet, Yet, in the 1998-2002 period, electricity and transportation costs decreased significantly, and telecommunications tariffs were shed drastically. Progress in lowering telephone costs in Vietnam has been good, although China and the Philippines fared even better. Rents appear to be relatively expensive in Vietnam, taking into account its lower-than-average GDP. Transport costs, on the contrary, are broadly in line with regional standards. 
Table 1. Business operating costs in Vietnam and other Asian countries

\begin{tabular}{lccccc}
\hline \multicolumn{7}{l}{ a. Vietnam and other countries } \\
$\begin{array}{l}\text { Office rent } \\
\text { US } \$ \text { /m2/month }\end{array}$ & $\begin{array}{c}\text { Telephone cost } \\
\text { 3 minute call } \\
\text { to Japan US\$ } \$\end{array}$ & $\begin{array}{c}\text { (\% change } \\
\text { 2000-2) }\end{array}$ & $\begin{array}{c}\text { Electricity } \\
\text { Cent/Kwh }\end{array}$ & $\begin{array}{c}\text { Transport } \\
\text { Cost of } \\
\text { 40 feet container } \\
\text { to Yokohama (US\$) }\end{array}$ \\
\hline Hanoi & 22 & 5.6 & -29 & 6 & 1470 \\
HCMC & 21 & 5.6 & -29 & 6 & 1078 \\
Manila & 7.5 & 1.2 & -42 & 3.5 & 700 \\
Beijing & 37 & 2.9 & -33 & 4 & 734 \\
Jakarta & 17 & 3.8 & +25 & 4 & 820 \\
Bangkok & 10 & 2.1 & -17 & 4 & 1304 \\
KL & 16.3 & 1.4 & 63 & 5 & 884
\end{tabular}

b. Progress within Vietnam

Monthly wage for worker (US\$)

Business cost changes 1998-2002

Office rent (US\$/month/m2)

$+9 \%$

3 minute call to Japan (US\$)

$-1 \%$

Power cost (cent/kwh)

$-72 \%$

40 foot container to Yokohama (US\$)

$-20 \%$

Source: VBF 2003

In sum, the analysis of comparative "cost of doing business" data shows that the above-mentioned businesspeople claims are by and large true, although by themselves they constitutes no indictment of wrong policy-making on the part of the government, as a country at the overall development level of present-day Vietnam cannot be expected to match much richer neighbors in domains such as the technological advancement and efficiency of services industries. ${ }^{29}$ Rather, it is encouraging to note that Vietnam has made a lot of progress in this area since the late 1990s, and especially so with respect to telecommunications costs. Yet, there is clearly no room for complacency, and it is crucial that the announced policy of gradual tariffs reductions and homologation keeps being consistently implemented. ${ }^{30}$

\footnotetext{
${ }^{29}$ Ceteris paribus, poorer countries' comparative advantages are mainly, almost by definition, determined by lower labor costs. In 2002, Vietnam's monthly wages for unskilled workers were 97.5 US $\$$ and 117.5US \$ respectively in Hanoi and HCMC, against 108 US\$ in Jakarta, 120 US\$ in Beijing, 150 US\$ in Manila, 163 US\$ in Bangkok, and 208 US\$ in Kuala Lumpur.

${ }^{30}$ The government Pricing Committee presented to the Forum a schedule for the phasing out of dual pricing. The schedule shows that, between 1998 and 2003, previously large differences between prices for locals and for foreigners have been progressively eliminated in water (from $117 \%$ to 0 ), and much reduced in power and air transport. The corresponding in difference in telephone installation was smaller $(6 \%)$ and was eliminated in 1999. Yet, it remains high (100\%) in TV advertising. In 2003, dual pricing was scheduled to be totally eliminated in airfares, rail and sea port fares, and in 2004 in electricity.
} 
However, tariffs policy is only one aspect of Vietnam's policy approach to the development of strategic services sectors, which strive to balance various requirements which are potentially conflicting with each other. On one hand, key infrastructural sectors are being opened up and partially liberalized, in order to make possible to reach a mutually acceptable compromise with trade partners, with a view to foster efficiency and technology upgrading and to improve Vietnam's systemic competitiveness via a progressive abatement of core business operating costs. On the other hand and, the government does not underestimate the crucial need to maintain in the long run a certain degree of strategic control on the development of core services industries.

\section{B. De-monopolization and internationalization of the Vietnamese energy industry}

Notwithstanding the strong growth achieved in the 1990s (with energy and electricity demands growing 30\% and 70\% faster than GDP respectively), Vietnam is one of the countries in the world with the lowest per capita consumption of modern forms of energy, ${ }^{31}$ with about two thirds of total energy consumption still stemming from traditional energy (wood and other biomass), and more than half the population lacking access to electricity. Therefore, a fast expansion of the energy sector continues to be a first-class priority. This task is facilitated by Vietnam's ample natural energy resources in oil, coal, gas, and hydropower. Yet, to tap this potential, it has been estimated that Vietnam should invest in the energy sector over 5\% of GDP (twice as much as its South Asian neighbors, already endowed with a more developed energy infrastructure). In order to match such huge financing needs, Vietnam - besides progressively restructuring its tariff policies - must be able to attract foreign funds, both as FDI flows and as stateguaranteed loans, creating an "enabling business environment" and a supportive legal framework (World Bank 1999).

The core of Vietnam's energy sector is constituted by few very large SOEs Electricity of Vietnam (EVN), PetroVietnam, Vinacoal, and Petrolimex - which employ over 200000 workers and have a combined turnover over 2.5 billion. In 1995, they were made state corporations under the State Enterprise Law, in order to facilitate the separation of ownership and management, with property rights entrusted to an independent management board. Yet, state corporations, and EVN in particular, failed to achieve an adequate degree of effective independence.

\footnotetext{
${ }^{31}$ Vietnam's energy consumption per capita in 1998 was only $144 \mathrm{~kg}$. of oil equivalent, about one seventh of Thailand's. India's energy consumption was 248 kg., China's 664 Kg,, Korea 2982 kg. (World Bank. 1999).
} 
Moreover, the separation of responsibilities and decision powers lacks clarity because ownership and other functions were diffused among various government agencies and ministries (Sedin 1998).

Previously fully-monopolistic energy sub-sectors have undergone major changes in recent years, and large energy SOEs are partially changing their roles. Petrovietnam, an efficient SOE which contributes substantially to Vietnam's balance of payments, ${ }^{32}$ plans to complete by 2005 a major gas-power-fertilizer project in $\mathrm{Ca} \mathrm{Ma}$, including a $332 \mathrm{~km}$ pipeline to carry 2 million cubic meters of gas per year, a 720 megawatt power plant (which is expected to use 1.5 billion cubic meters of gas per year) and a 800000 tons fertilizer plant. Petrovietnam is also growing more internationalized. It already operates several joint ventures, and is seeking other cooperation contracts with foreign investors interested in Vietnam's energy resources. It also ventured in Iraq and Algeria, and has bought shares of international oil corporations in Mongolia and Malaysia (Viet Nam News July 4).

The state retains monopoly on transmission for many reasons, security included, but production and generation are being gradually opened to competition (see DGPT 2002). EVN's monopoly in electricity generation has been superseded since 1998, when the fully foreign-owned 375-MW Hiep Phuoc Plant began operating. EVN has also been experimenting with divesting some distributor units, but the equitization process has been hampered by difficulties in the price setting mechanism, as rural electricity prices are lower than corresponding production costs.

Presently, EVN is buying electricity from many domestic and foreign-invested firms ${ }^{33}$ which operate under BOT agreements. Other foreign- and locally-invested energy plants are scheduled to be put into operation soon. 30 plants have been already identified for investment by domestic enterprises other than EVN, with a total capacity of $3684 \mathrm{MW}$ in the next 7 years. ${ }^{34} \mathrm{EVN}$ also seeking to attract FDI to contribute financing six joint ventures expected to create $2623 \mathrm{MW}$ of combined additional generation capacity. According to plans, foreign and domestic non-

\footnotetext{
${ }^{32}$ Crude oil exports in January- June 2003 were almost 8.6 million, 3\% up on same period in 2002 year (Viet Nam News, July 4, 2003).

${ }^{33} \mathrm{EVN}$ presently buys energy from 5 foreign-invested plants. Other 40 non-EVN plants will sell energy to EVN from next year.

${ }^{34} \mathrm{As}$ a result, Vietnamese private investors are expected to finance $36 \%$ of total investment in power generation in the 2002-2010 period.
} 
EVN energy firms and foreign will provide over $60 \%$ of total investment in power generation for the 2002-2010 period (Dao Van Hung 2003). The Vietnamese government has also recently embarked in a power saving program. ${ }^{35}$

The power sub-sector strategy is aimed at relieving EVN of part of the burden constituted by the need to meet ever-increasing investment needs, taking into account that its pricing policy is constrained by the public service nature of electricity services, which must be kept affordable especially for rural users. However, EVN's dominating position, rather than being superseded by competition, will have to be re-focused towards expanding the distribution network and ensuring a regulated exploitation of energy resources. EVN management, aware of the frequent failures of privatized and poorly regulated energy systems both in developed and developing countries, realize that the new strategy is not without risks, as new energy-generating enterprises lack experience and often exhibit high operating costs. Moreover, due to the tightness of the overall supply-demand balance, power shortages cannot be ruled out, unless a very accurate planning and coordination of the decentralized generation system can be assured (Dao Van Hung 2003).

Further reform in the domain of energy services, in order to achieve an adequate degree of competition and to mobilize the vast financial resources needed to fuel Vietnam's industrialization process, might require further steps towards stressing energy SOEs' commercial orientation and improving their corporate governance, de-bunking more generation, transmission, and distribution functions, restructuring energy markets, and developing an effective legal and regulatory framework (World Bank 1999). Yet, as numerous experiences in reforming energy utilities in other developing countries have shown, it is also imperative that the State maintains a strong, albeit more flexible, strategic control on the development of the energy sector (see Gabriele 2003).

\footnotetext{
${ }^{35}$ The Vietnamese government has approved a technical assistance project on management of power supply and power saving. The project is worth US\$6.23 million, out of which US\$5.5 million ares granted by the Global Environment Facility (GEF) via the World Bank. The first stage of the project is aimed at reducing peak loadings by 120 megawatt during the next three years, installing 5,600 electronic electricity meters for heavy power consumers, and launching a pilot power management program to reduce power demand on the part of 2,000 consumers. It also intends to save 500 gigawatt/ hour by selling 1,000 energy-saving lights to households located in areas with peak load demand. The second stage of the project is designed to assist industrial and commercial power consumers in order to reduce production costs for domestic productive businesses and to enhance the competitiveness of their products (Viet Nam News, 29 May, 2003).
} 


\section{The liberalization of the telecommunications sector in Vietnam ${ }^{36}$}

The Vietnamese telecommunications sector is one of the fastest-developing in the world, second only to China in terms of growth (over $20 \%$ per year since the early 1990s), coverage expansion, and technology renewal. New fixed line provision increased from 80000 in 1986 to over 4 million in $2002 .{ }^{37}$ In spite of fast development in the last decade, the tele-density rate are still low (5.44 lines per 100 people in 2002). ${ }^{38}$ Yet, mobile telephony and Internet are booming after a later start: there are now over two million mobile users ( a figure expected to double by 2005) in Vietnam (Vietnam News, July 2, 2003), and Internet subscribers number in the hundreds of thousands. ${ }^{39}$ These figures, while testifying the impressive modernization effort carried out in recent years, indicate the huge growth potential of the telecommunications market in Vietnam, taking into account the size of its population and the rapid growth path on which the economy has embarked.

The structure of the Vietnamese telecommunications sector is complex, on one hand, due to the numerous players in the market, and simple, on the other hand, as the government is still fundamentally in control. ${ }^{40}$

\footnotetext{
${ }^{36} \mathrm{~A}$ more detailed sectoral analysis on Vietnam's telecommunication policies can be found in a twin paper (Gabriele 2003a).
${ }^{37}$ Massive telecommunications investment has been financed to a large extent through external funding, under the forms of structured loans, ODA, and FDI (over one billion US\$) channeled into BCCs and joint venture arrangements. As a result, the Vietnamese telecommunications market reached 600 US\$ millions in 2001.

${ }^{38}$ Thailand has 7 lines per 100 people, Malaysia 15 (BICA 2003, p. 223)

${ }^{39}$ Internet users in Internet cafes are probably in the millions.

${ }^{40}$ The Ministry of Post, Telecommunications and Information Technology (DGPT) - which was split in two in 2003 between a body governing the post system as such and another supervising the telecommunications and information sector proper - operated directly as business operator until the mid-1990s through the state-owned Vietnam Post and Telecommunications Corporation (VNPT) in what was effectively a fully monopolistic market, both in the domain of services provision and in that of infrastructure development. In 1996, a process to promote limited internal competition in the telecommunications sector began, when operating licenses were issued to Saigon Post and Telecommunications Services Corporation, a joint stock company in which VNPT held a large share of the equity. Subsequently, operating licenses were issued to Vietel, the army's telecommunications company, the Vietnam Maritime Communications and Electronics Company (VISHIPEL), and the Electric Telecommunications Company (ETC). However, the DGPT substantially retains so far its ability to vet foreign purchase agreements, network structures, and issue operating licenses, and VNPT is still the dominant player in the telecommunications market. VNPT also controls, either directly or via equity arrangements and joint ventures, over 200 subsidiary companies, active in the domains of equipment, manufacturing and sourcing and in a number of support services such as R\&D, infrastructure construction, fixed line installation, and transportation. As a result, Vietnam's telecommunications sector has a very high degree of vertical integration (BICA 2003, p.224). 
Apart from the implications of the BTA and of ongoing WTO access negotiations (see above, section 3), the most importance recent policy measure is the Ordinance on Posts and Telecommunications No.43, issued in 2002, which formally established the legal conditions for the development of a competitive market in telecommunications services consistently with existing WTO discipline (see VBF 2002). The Ordinance defines the roles of different actors in the liberalized telecommunication market. Public networks, which provide services to the public at large and are the only ones allowed to set up international communication networks, can only be established by Vietnamese telecommunications enterprises. Conversely, private networks, which can be foreign-owned, provide services to a limited group of users. ${ }^{41}$ The Ordinance also mandates to set up an open interconnection regime, to which all operators can connect at "fair and equitable" conditions, supervised by a regulator. Telecommunications tariffs remain subject to stringent regulation.

\section{Main goals of policies in the domain of strategic services sectors}

The preceding sub-sections sections has reviewed the major changes and policy initiatives in two strategic services sectors, energy and telecommunications. In both sectors, it appears that a model with some distinctive characteristics is taking shape, following closely the - so far successful- example of China. It is structured around several SOEs (one of which, nevertheless, retains a dominant position), acting in cooperation with foreign TNCs (via BCCs, joint ventures, and/or similar legal arrangements), in a moderately competitive market jointly molded by government policy guidelines and by a WTO-compatible independent public regulatory agency.

In this endeavor, Vietnam's policy makers are implicitly carrying out a complex exercise of constrained dynamic optimization, which inevitably implies significant trade offs, and can only pragmatically lead (in the best scenario) to what might

\footnotetext{
${ }^{41}$ Telecommunications enterprises (all of which must obtain licenses) are either a Network Infrastructure Providers (NIP) or a Service Provider (SP). A NIP is broadly similar to what in other countries' regulatory regimes is called a "Carrier".Only NIPs, which must be a SOE or controlled by the state, can supply all categories of telecommunications services, and may set up the necessary network infrastructure. The Explanation Memo attached to the Ordinance further explains why only SOEs can be NIP: "For telecommunications, network infrastructure is the most important factor relating to national sovereignty, therefore only certain SOEs or other enterprises where the state makes controlling capital contributions are allowed to construct, operate and manage the network". Yet, foreign enterprises may enter into investment cooperation arrangements with Vietnamese firms, NIPs included, according to Vietnam's undertakings in bilateral and multilateral trade agreements.
} 
approximately be considered a second-best solution. ${ }^{42}$ Planners' goals are multiple and, while not mutually incompatible, imply reciprocal trade-offs and thus must be assigned proper weights. The major ones can be assumed to be as follows:

(1): to maintain strategic policy control;

(2): to maximize the rate of service improvements and cost reduction, thereby contributing to diminish the "cost of doing business" and to improve the country's international competitiveness and FDI-attractiveness;

(3): to promote technical progress and technological absorption;

(4): to build up a "nationally-owned" entrepreneurship, mainly centered on few large SOEs;

(5): to enhance synergies between the energy and telecommunications industries and other domestic industrial sectors;

(6): to ensure a high investment rate, channeling towards strategic services sectors sufficient domestic resources, attracting FDI on the part of large foreign telecommunications enterprises, and obtaining funds from official and private lenders;

(7): to minimize the capture of monopolistic and quasi-monopolistic rents on the part of foreign TNCs;

(8): to ensure the fulfillment of public services, equity-oriented obligations.

\section{Concluding Remarks}

This study has reviewed some basic features of Vietnam's services sector and of the policies been implemented in the domain of services.

On this basis, it has attempted to interpreter and evaluate the role and consistency of both domestic and trade policies affecting services in the framework of the country's broader strategic framework of outward-oriented reforms aimed at fostering industrialization and building up a strong market economy oriented towards socialism. The main conclusions are as follows.

In the domain of infrastructural strategic services, Vietnam has committed to a quite relevant degree of liberalization and opening to international trade in the telecommunications sector, more so than in the energy and transport sectors.

\footnotetext{
${ }^{42}$ Such an exercise is similar to that carried out by planners in other core infrastructural sectors, such as energy or transportation, but in the case of telecommunications it is made more difficult by the fast rate of technological change and the related crucial importance of the technological implications of the sector's development on the economy as a whole.
} 
Besides responding to pressure stemming from actual and perspective trading partners in the complex web of trade negotiations which led to the signing of the BTA, and are expected to pave the way to Vietnam's accession to WTO, policymakers strive to achieve a certain degree of regulated competition in the market, with the two pivotal goals of capturing competition-related benefits in terms of efficiency and competitiveness and of absorbing more advanced technologies from foreign companies. Yet, even after the phasing out of state monopoly, the Vietnamese telecommunications market, like those of most other countries, retains a strongly oligopolistic structure, although more open and sharpened competition is likely to emerge in a few marginal niches. The role of the state, far from being minimized, is envisaged to be strengthened in a new and modernized way, with a division of tasks between different public actors. SOEs are expected to enhance their direct entrepreneurial and managerial role as the largest firms and the main partners of TNCs in the domestic market. The Ministry of Planning, the line ministries, and the other bodies and committees which directly supervise telecommunications and the other infrastructural industries, try to streamline, rationalize and make more effective their strategic planning role. Finally, sectoral regulatory functions are being transferred to a separate agency which, according to policy design, should enjoy a high degree of autonomy, thereby being able to safeguard an acceptable measure of competition (an outcome which, by its very oligopolistic nature, the telecommunications market would not produce spontaneously), and to protect the legitimate interests of both households and business users.

Another important component of telecommunications policies is tariff policy. The policy choice of gradually lowering tariffs, in telecommunications as in other key public services, constitutes a progressive transfer of resources from the dominantly state-owned, large scale, capital-intensive, and arguably importsubstituting infrastructural services sectors, towards other areas of the economy, and especially towards labor-intensive, small scale, and mostly non-state owned manufacturing and services activities. Such a transfer amounts to a progressive lowering of the level of effective protection for the telecommunications industry (or, at least, of the impact of one of the most powerful instruments traditionally used to enforce it), which is necessary to strengthen the competitiveness of those sectors of the Vietnamese economy which do enjoy a comparative advantage under present circumstances, besides attracting FDI. Yet, it is important that such re-orientation of inter-sectoral transfers in favor of the full exploitation of static 
comparative advantages is balanced by a strengthened commitment to allow telecommunications SOEs to retain sufficient investment funds, and by a reconfirmation at the highest planning level of the strategic priority accorded to the development of the national telecommunications industry.

In the domain of the international trade dimension of services policies, Vietnamese policy-makers strive to achieve a certain degree of consistency with the diverse strategic goals pursued in the different services sectors. The focus of negotiations on infrastructural and financial strategic services, which are the core component of overall negotiations on trade in services, is on the domestic market. Vietnam needs to strengthen already-existing but insufficiently competitive, efficient and technologically advanced national firms, but must be careful not to allow them to be swallowed by powerful TNCs enterprises, thereby losing strategic control and risking ending up as a hostage of foreign private monopolies ${ }^{43}$. Policy makers realize they have to walk a fine line, striving to open up the market to foreign operators to a significant but not unlimited extent. In this endeavor, on one hand, they try to reap the benefits of competition and facilitate the absorption of more advanced technologies and management techniques, and on the other hand, necessarily, they are responding to external negotiating pressures in a zero-sum game.

In sum, Vietnam's integrated policy approach to reforms in strategic services sectors appears to show a certain degree of internal coherence. Vietnam's policy makers see market-oriented reforms of core infrastructural services sectors and international integration as two necessary and mutually consistent policy tools to enhance the country's overall development perspectives. However, in doing so, they are cautious not to relinquish the fundamental guidance and planning responsibilities of the State, in order to maintain a flexible, yet effective degree of strategic control, as it is ultimately the only guarantee that the overall liberalization and international integration process effectively works for the sake of Vietnam's own economic and social development, rather than falling pray of domestic and external particularistic interests.

This complex scenario is, of course, unique to Vietnam and to the specific historical conditions prevailing in that country, although the similarities with the

\footnotetext{
${ }^{43}$ Abstracting from the role of SOEs, the main "defensive" instruments which the Vietnamese government is bound to maintain, apart from the role of SOEs, are the licensing policy and the broad planning and regulatory functions of the State. Yet, such instruments will have to be employed in a conservative, cautious, and WTO-compatible fashion.
} 
Chinese experience are remarkable. Yet, a more general lesson might be tentatively extrapolated from Vietnam's experience, relevant especially for those developing and transition countries which built up a diversified, albeit relatively inefficient, industrial and infrastructural base under conditions of separation from the main trends in international markets. Policy-makers should approach market-oriented reforms and international integration with gradualism, and strive to maintain and strengthen the State's ability to steer the overall process of change towards national development priorities through the creation of innovative forms of strategic planning.

\section{Annex: The Services Sector in Vietnam: Facts and Figures}

\section{A1. The evolving role of services in the Vietnamese economy}

In the most recent period, the Vietnamese economy has progressively recovered from the slow-down caused by the impact of the Asian crisis, achieving a sustained growth path (see Table A1.I).

To be interpreted correctly, data in Table 2 need an important qualification. According to a classification criterion common to many countries, Vietnam's General Statistical Office (GSO) includes "Electricity and Water" and "Construction" in the "Industry and Construction" macro-sector, rather than in the "Services" one. Yet,

Table A1. Vietnam: GDP growth by major sectors, 1999-2002

\section{Growth rates (in 1994 constant prices)}

\begin{tabular}{lcccc}
\hline & 1999 & 2000 & 2001 & $2002^{*}$ \\
\hline GDP & 4.8 & 6.8 & 6.9 & 7 \\
Agriculture, forestry, aquaculture & 5.2 & 4.6 & 3 & 4.1 \\
Industry and construction & 7.7 & 10.1 & 10.4 & 9.4 \\
Services & 2.3 & 5.3 & 6.1 & 6.5 \\
\hline
\end{tabular}

II. Sectoral shares in GDP (\%)

\section{A. In current prices}

Agriculture, forestry, aquaculture Industry and construction

Services

\section{B. In 1994 prices}

Agriculture, forestry, aquaculture Industry and construction

Services

Source: CIEM 2003, GSO 2002 *Estimates

\begin{tabular}{lccc}
25.4 & 24.3 & 23.2 & 23 \\
34.5 & 36.6 & 38.1 & 38.6 \\
40.1 & 39.1 & 38.7 & 38.4 \\
& & & \\
23.7 & 23.2 & 22.4 & 21.8 \\
34.4 & 35.4 & 36.6 & 37.4 \\
41.9 & 41.4 & 41 & 40.8 \\
\hline
\end{tabular}

25.4

34.5 
Table A2. Vietnam : GDP contribution by Sectors, 1995-2001

\begin{tabular}{|c|c|c|c|c|c|c|c|}
\hline & 1995 & & 1998 & & 2001 & & \\
\hline & $\begin{array}{l}\text { GDP contribution } \\
\text { (Bn of VND, } \\
\text { current) }\end{array}$ & $\begin{array}{c}\text { GDP share } \\
(\%)\end{array}$ & $\begin{array}{c}\text { GDP contribution } \\
\text { (Billions of VND, } \\
\text { current) }\end{array}$ & $\begin{array}{c}\text { GDP share } \\
(\%)\end{array}$ & $\begin{array}{l}\text { GDP contribution } \\
\text { (Bn of VND; } \\
\text { current) }\end{array}$ & $\begin{array}{c}\text { GDP share } \\
(\%)\end{array}$ & $\begin{array}{c}\text { Average } \\
\text { Growth rate } \\
1996-2001 \\
\text { (in current } \\
\text { prices) }\end{array}$ \\
\hline$\overline{\text { SERVICES (macro-sector) }}$ & 100.8 & 44.0 & 150.7 & 41.7 & 186.8 & 38.6 & 10.8 \\
\hline Trade & 37.5 & 16.4 & 55.8 & 15.5 & 67.9 & 14.0 & 10.4 \\
\hline Hotels \& Restaurants & 8.6 & 3.8 & 12.4 & 3.4 & 15.8 & 3.3 & 10.7 \\
\hline Transportation \& Telecom & 9.2 & 4.0 & 14.1 & 3.9 & 19.4 & 4.0 & 13.2 \\
\hline Finance, Banking \&Insurance & 4.6 & 2.0 & 6.3 & 1.7 & 8.8 & 1.8 & 11.4 \\
\hline Science \& Technology & 1.4 & 0.6 & 2.0 & 0.6 & 2.7 & 0.6 & 11.6 \\
\hline Real Estate and Renting & 12.4 & 5.4 & 17.7 & 4.9 & 21.6 & 4.5 & 9.7 \\
\hline Public Administration & 8.3 & 3.6 & 11.9 & 3.3 & 12.6 & 2.6 & 7.2 \\
\hline Education \& Training & 8.3 & 3.6 & 13.2 & 3.7 & 16.5 & 3.4 & 12.1 \\
\hline Healthcare and Social Welfare & 3.6 & 1.6 & 5.0 & 1.4 & 6.4 & 1.3 & 10.1 \\
\hline Culture and Recreation & 1.3 & 0.6 & 2.1 & 0.6 & 2.7 & 0.6 & 13.0 \\
\hline Party and Association & 0.2 & 0.1 & 0.6 & 0.2 & 0.7 & 0.1 & 23.2 \\
\hline Community and Social service & 5.0 & 2.2 & 8.9 & 2.5 & 10.7 & 2.2 & 13.5 \\
\hline Private Household Employment & 0.5 & 0.2 & 0.8 & 0.2 & 1.0 & 0.2 & 12.2 \\
\hline Electricity and Water & 4.7 & 2.1 & 10.3 & 2.9 & 16.2 & 3.3 & 22.9 \\
\hline Construction & 15.8 & 6.9 & 20.9 & 5.8 & 27.4 & 5.7 & 9.6 \\
\hline GDP & 228.9 & 100.0 & 361.0 & 100.0 & 484.5 & 100.0 & 13.3 \\
\hline
\end{tabular}

Source: GSO 2002 
according to the WTO international trade classification (which is relevant for the focus of the present paper) "Electricity and Water" and "Construction" are considered as services. As the combined GDP share of "Electricity and Water" and "Construction" is about $9 \%$, the aggregate figures in Table 2 underestimate the true contribution of services to GDP, which is much larger than those of either industry proper or agriculture, and actually close to $50 \%$.

Employment patterns, as it is normal in a largely rural and subsistence-oriented economy as Vietnam's, diverge markedly from those of GDP contribution. Over 2/3 of the Vietnamese labor force is still in agriculture. Industry accounts for about $12 \%$ of total employment, and services for almost $20 \%$ (in 2000). Services' employment share has been rising slowly, from less than 16\% in 1990 (source: EAEP 2003). Yet, these figures underestimate services' contribution to employment, as they fail to account for urban and rural informal services employment. In practice, as industry is developing fast but - especially in the still dominant state-owned sector -along a path characterized by high productivity growth but relatively little job creation, most non-rural workers are formally or informally employed in services activities.

GDP in the (narrowly-defined, i.e. excluding electricity, water, and construction) services (macro)-sector has been expanding at an intermediate rate between the very fast one of industry and the lower - yet healthy - one of agriculture, forestry, and aquaculture (Table I). As a result, services ${ }^{44}$ sectoral share in GDP has been slowly declining, and in 2002, for the first time, narrowly-defined services ${ }^{45}$ have been overtaken by industry as the largest sector of the Vietnamese economy (Table IIA). ${ }^{46}$ Yet, the share of services ${ }^{47}$ in the economy is not small in Vietnam, taking into account its level of development. It is in fact higher than China (33.6\%) and Indonesia (37.1\%) (CIEM 2003, p. 19).

With respect to prices, it can be observed that the relative prices "scissor" moved against services ${ }^{48}$, as their GDP share in 2002 was higher if measured at

\footnotetext{
${ }^{44}$ Narrowly-defined.

${ }^{45}$ Narrowly-defined.

${ }^{46}$ Also the combined GDP share of electricity, water, and construction remained basically the same (at 9\%) between 1995 and 2001 (source: GSO).

${ }^{47}$ Narrowly-defined.

${ }^{48}$ Narrowly-defined.
} 
1994 prices (40.8) than at current prices (38.4)(see Table IIA,B). The opposite is true for agriculture and industry. This trend is also to be interpreted as a positive one, as backwardness and high prices in key services sectors have been identified among the main causes of relatively high production and distribution costs and -generally speaking - "costs of doing business", thereby hampering Vietnam's international competitiveness. One important factor in this trend in relative prices is the progressive lowering of tariffs for public services, which are still high but diminishing (see below, sub-section 2.4.) ${ }^{49}$.

These figures, taking into account the early stage of industrialization Vietnam is presently going through, show a rather healthy and balanced growth pattern: the services sector does grow fast, but industry grows faster. ${ }^{50}$ Therefore, while developing its services activities at an adequate speed, Vietnam is avoiding the trap of unwarranted and perverse earlier "servicization" of the economy, which leads many developing countries, and especially LDCs, to superficially resemble the productive structure of the most advanced industrialized countries. ${ }^{51}$ While in some cases such "servicization" might in fact suit to some extent the resource endowments and comparative advantages of less advanced countries (many of which, for instance, rely heavily on tourism), it also signals a failure to advance on the path of industrialization, and is usually an omen of an unbalanced and poorly integrated overall development pattern.

\section{A2. The main services sectors in the Vietnamese economy}

Turning to the various services sectors, it is useful to focus first on those abovementioned two which GSO classifies outside the services macro-sector, "Electricity and Water" and "Construction". Both are rather large, especially the latter, which is actually the third largest services sector after "Trade" and "Hotels and Restaurants". Electricity and water is one of the fastest growing sector of the Vietnamese

\footnotetext{
${ }^{49}$ This trend appears to be have been continuing in 2003. It can be assumed that the relative prices trend stems basically from efficiency gains and price policies of large utilities (such as telecommunications, transport, and energy) rather than from the small-scale, competitive, and largely non-state owned small services sector activities.

${ }^{50}$ The fact that agricultural growth has also been sustained, albeit inevitably slower, is also important, taking into account that over $70 \%$ of Vietnamese still leave in the countryside.

${ }^{51}$ While in very poor countries unhealthy "servicization" is simply the mirror image of a failure to industrialize, in more advanced countries it can be the result of "premature de-industrialization". This is the case, in particular, in many Latin American countries (see UNCTAD 2003, Chapter V).
} 
economy in this period, expanding even more rapidly than the booming and increasingly export-oriented manufacturing sector, and the only services sector whose GDP share increased in 1995-2001 (see Table A2) ${ }^{52}$. This is consistent with its key role as a core infrastructural sector, and particularly as one of the two mature capital-intensive services industries (the other being transportation, which GSO lumps along with a relatively new and ITC-intensive services industry, telecommunications, in the "Transportation and telecommunications" sector). Moreover, the power industry in particular is still relatively under-developed, ${ }^{53}$ and therefore deserves a high priority in investment allocation to prevent it from becoming a bottleneck to further industrial development.

Among the other services sectors, by far the largest is that of trade, the relative GDP share of which was $14 \%$ in 2001. However, that share, as well as that of "Hotels and restaurants" has been decreasing to some extent since the mid-1990s, possibly pointing towards an on-going diversification process inside the services sector. Such a trend is not clearly emerging yet as an established one, but an encouraging signal comes from the embryonic "Science and Technology" subsector, which has been growing very fast since $2000^{54}$, and from "Education and Training" (see Table A2). Both sectors have been selected as key ones by the Government for the promotion of human capital formation. Of more immediate macroeconomic relevance is the growth of the tourism sector (imperfectly captured by the GSO statistical classification), which boomed in 2002, with over 2.6 million international visitors and a revenue growth rate of $20 \%$ over 2001 , helped by the fact that Vietnam was recognized as the safest destination in $\mathrm{Asia}^{55}$ (CIEM 2003, p.18).

Such overall encouraging trends in the domain of services, however, are still inadequate to sustain the development of many skill-intensive services with a high potential for value added generation, and which can contribute to a large extent to raise the country's overall competitiveness and to fasten the industrialization process

\footnotetext{
${ }^{52}$ Table 3 shows that the "Party and association" sector grew even faster than electricity and water. Yet, it is a very small sector with negligible economic significance.

${ }^{53}$ Although increasing, the GDP share of "Electricity and water" is still small, around 3\% (see table 3).

${ }^{54}$ According to preliminary estimates, Science and Technology and Education and Training grew respectively $9.5 \%$ and $8.5 \%$ in 2002 (CIEM 2003).

${ }^{55}$ The tourist sub-sector, unfortunately, was severely hit by the SARS epidemic in the spring of 2003, but recovered thereafter.
} 
(among them, "service industries" such as telecommunications, energy, and transport, financial services, and several specialized business-supporting services).

Received 25 January 2004, Accepted 1 April 2004

\section{References}

Amsden, A. (1989) Asia's Next Giant: South Korea and Late Industrialisation. Oxford: Oxford University Press.

Auffert P., 2003, Trade Reforms in Vietnam: Opportunities with Emerging Challenges, World Bank Working Paper No. 3076.

BICA 2003 ( Building Institutional Capacity in Asia, project commissioned by the Ministry of Finance, Japan), 2003 Report, Re-Defining the Borders Between public and Private in Southeast Asia.

Central Institute for Economic Management (CIEM), 2003, Vietnam's Economy in 2002, Hanoi

Dao Van Hung, General Director of Electricity of Vietnam (EVN), 2003, interview with Vietnam News, 10 July.

Dapice D., 2002, Success and failure: Choosing the Right Path to Export-Led Growth, Center for Business and Government, Harvard University; June.

Dollar D., 2002, Reform, Growth, and Poverty in Vietnam, World bank Working Paper No.: 2837, May.

DGPT (Department of General Posts and Telecommunications) 2002, Annual report 2002, Hanoi.

East Asian Development Perspectives (EAEP), 2003, Recent Trends and Prospects for Major Asian Economies, Vol.14, No.1, February, The International Centre for the Study of East Asian Development, Kitayushu.

Fforde, A., and de Vylder, S. (1996) From Plan to Market: The Economic Transition in Vietnam. Boulder (Colo.): Westview Press.

Gabriele A., 2003a, Telecommunication Policies in Vietnam, UNCTAD (mimeo).

Gabriele A., 2003b, Social services policies in a developing market economy oriented towards socialism: the case of health system reforms in Vietnam, UNCTAD (mimeo). Government of Vietnam (GOV), 2000a, Strategy for Socio-Economic Development 20012010 - Strategy for accelerated industrialization and modernization along the socialist line, laying the foundations for Vietnam to become by 2020 basically an industrialized country (Presented by the Central Committee, Eighth Tenure, to the Ninth National Party Congress).

Government of Vietnam (GOV), 2000b, Agriculture and Rural Development 5-Year Plan (2001- 2005), Ministry of Agriculture and Rural Development Hanoi, 22 August 2000.

Government of Vietnam (GOV), 2001a, The 5-year plan for socio-economic development 
(2001-2005), Ministry of Planning and Investment, Hanoi, October 16th 2001. Government of Vietnam (GOV), 2001b, Hunger Eradication and Poverty Reduction Strategy, Ministry of Labor, Invalids and Social Affairs, May 2001.

Government of Vietnam (GOV), 2001c, Vietnamese Education and training Development Strategy to the year 2010 for the Cause of the Industrialization and Modernization of Vietnam, Ministry of Education and Training, Hanoi, March 2001.

Government of Vietnam (GOV), 2001d, Prime minister's decision on Approval of Strategy for people's Health Care and Protection 2001-2010, Hanoi, 19 March 2001.

Government of Vietnam (GOV) 2002, Comprehensive poverty reduction and growth strategy (CPRGS), Hanoi.

Government of Vietnam (GOV) and Government of the U.S. of America, 2001, Agreement between the Socialist Republic of Vietnam and the United States of America on trade relations (BTA).

Government of Vietnam (GOV) 2003, Revised Offer on Specific Commitments in services to members of the WTO Working Party on Accession of Vietnam, WTO Doc. WT/ACC/SPEC/VNM/2/Rev.1, \& March 2003 Restricted

General Statistical Office (GSO), 2002, Socio-Economic Situation in 2002, Hanoi, December. International Monetary Fund- International Development Association (IMF-IDA) 2002, Joint Staff Assessment of the Poverty Reduction Strategy, Hanoi, June.

Larsen T.I., Viet Tuan Dinh and Rama M., 2003, Taking Stock - An update on Vietnam's Economic Development and Reforms. Progress and donor Support (Report to the mid-Year consultative group meeting held in sapoa D.S.L, June 19-21, 2003).

Kolko, G. (1997) Vietnam: Anatomy of a Peace. New York and London: Routledge.

Kokko, A. (1998) Managing the Transition to Free Trade: Vietnamese Trade Polocy for the $21^{\text {st }}$ Century. Policy Discussion Paper No. 98/05, Centre for International Economic Studies, University of Adelaide.

Masina P. (ed.), 2002a, Rethinking Development in East Asia - From Illusory Miracle to Economic Crisis, Nordic Institute of Asian Studies, Curzon Press, Richmond, Surrey, pp.326.

Masina P., 2002b, Introduction, in Masina 2002a, pp.1-28

Masina P., 2002c, Dealing with the crisis in Vietnam: The rethinking of development Strategies, in Masina 2002a, pp.223-240

Masina 2002d, Conclusion, in Masina 2002a, pp.1319-323.

Masina 2003, Vietnam after the regional economic crisis - reflections on development strategies, Ph.D. Dissertation, Dept. of Social Sciences, Roskilde University, April.

Nhat B.X., Anh T.N., and Schmidt U., 2001, Inter-Ministerial Coordination during WTO Accession - Experiences of Selected (Transition) economies and Some Considerations for Vietnam, Prime Minister's Research Commission and Vietnam Institute for Trade, Hanoi, August

Schmidt U., 2002, Roadmap for Vietnam's Accession to the WTO - A contribution to a rational approach in trade liberalization (Policy study prepared at the request of the GTZ-CIEM project “Support for Vietnam's Economic Reform”, mimeo). 
Stiglitz J.E. and Yusuf S., 2001, (eds.), Rethinking the Asian Miracle, World Bank and Oxford University Press.

Star-Vietnam and Central Institute for Economic Management (CIEM) (STAR-CIEM), 2003, An Assessment of the Economic Impact of the United States- Vietnam Bilateral Trade Agreement, National Political Publisher, Hanoi.

UNDP 2003, Human Development Report 2003, New York.

Van Arkalde B., 2001, Vietnamese growth in the 1990's: lessons to be learnt, Report to UNCTAD, Geneva (mimeo).

Vietnam Business Forum (VBF), 2002, Market Liberalisation in Vietnam: Comments on the Ordinance on Posts and Telecommunications (2002) and the Draft Competition Law, Hanoi, August

Vietnam Business Forum (VBF), 2003, (collection of working papers presented to the mid-year Consultative Group Meeting of the Vietnam Business Forum held in Hanoi, June 6th, 2003), IFC, Hanoi.

Xuan Gia T., 2003, On Vietnam's 2001-2010 Socio Economic Development Strategy and 2001-2005 Five-Year Plan, Vietnam Social Sciences 1(93), pp.23-30

Wade, R. (1990), Governing the Market. Economic Theory and the Role of Government in East Asian Industrialization. Princeton (NJ): Princeton University Press, 1990.

World Bank(1993) The East Asian Miracle: Economic Growth and Public Policy, Oxford: Oxford University Press.World Bank 1993

World Bank 1999, Fueling Vietnam's Development - New Challenges for the Energy Sector

World Bank 2003, Vietnam-delivering on its promise, Country Development Report 2003, Hanoi. 